\title{
Um sombrio cenário promissor ${ }^{1}$
}

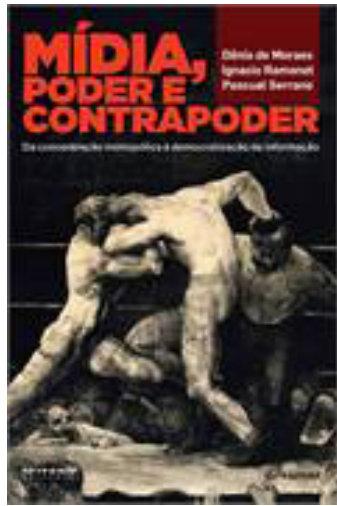

\section{Katarini Miguel}

Jornalista. Mestre em Comunicação pela Unesp/Bauru. Doutora em Comunicação pela Universidade Metodista de S.Paulo. Professora adjunta de jornalismo na Universidade Federal de Mato Grosso do Sul. katarini.miguel@ufms.br.

Com esse paradoxo do título, podemos definir a obra Mídia, poder e contrapoder dos renomados e já bastante conhecidos autores Dênis de Moraes, Ignacio Ramonet e Pascual Serrano, que traz textos elucidativos e que fluem com a acidez crítica necessária para os dias atuais.

O livro está dividido em duas partes - cada qual com um texto de cada autor. $\mathrm{Na}$ primeira parte, a total desilusão é reverberada com dados, exemplos drásticos (para não dizer cômicos) e críticas que nos fazem refletir sobre a decadência total e irreversível dos modelos midiáticos. Já a segunda apresenta uma importante clareira, ao descrever iniciativas e evidenciar as brechas do jornalismo digital frente aos monopólios midiáticos, cada vez mais excludentes. Tratamos de apreciar aqui as ideias seguindo essas duas divisões: a tempestade e a bonança.

1. “(...) no atual sistema de mercado não são os governos que aplicam a censura, são os meios de comunicação" (SERRANO, p. 78).

Dênis de Moraes é professor na UFF (Universidade Federal Fluminense), pesquisador conhecido com obras de forte viés marxista como Sociedade Midiatizada (Boi Tempo:

1 Moraes, Denis de, RAmonet, Ignacio \& Serrano, Pascual. Mídia, poder e contrapoder: da concentração monopólica à democratização da informação. São Paulo: Boitempo; Rio de Janeiro: FAPERJ, 2013. 
2006) e Globalização Mídia e Cultura Contemporânea (Letra Livre: 1997). No capítulo de abertura "Sistema midiático, mercantilização cultural e poder mundial", Moraes escancara seu desconforto, discorrendo sobre a glorificação do mercado, do individualismo e da competição, e a capacidade da mídia (ainda) de estabelecer sentidos e ideologias na opinião pública, de operar "consensualmente, para reproduzir a ordem de consumo e conservar hegemonias constituídas" (p. 21). Para o autor, a digitalização dos conteúdos midiáticos ao mesmo tempo em que promove novas formas de expressão e sociabilidade, agrava a concentração oligopólica, na medida em que poucos grupos fazem grandes investimentos em multiplataformas, alavancam seus negócios e operam pela mais valia da comunicação digital. Os conglomerados midiáticos persistem e são oportunistas ao apostar nas ferramentas digitais e se colocar, no emaranhado de informações da rede, como veículos de credibilidade. Moraes respalda suas afirmações com dados preocupantes, que evidenciam o alto nível de rentabilidade da mídia, com os perniciosos aportes e participações acionárias de empresas de petróleo e bancos, não só comprometendo a qualidade editorial, mas também sepultando o papel do jornalismo para o interesse público. Triste realidade.

A mercantilização nos diversos âmbitos sociais não escapa da análise do autor. Ele cita desde a indústria editorial, cinematográfica e artística, a restaurantes e igrejas, que investem na descentralização (gravar e publicar em países diferentes; oferecer comida que agrade o paladar local) como estratégia para contenção de despesas e aumento do lucro. O mercado se transveste de um pseudo multiculturalismo, que só é viabilizado, desde que passível de ser vendável. "As identidades locais funcionam como uma representação das diferenças comercializáveis" (MorAEs, p. 37).

A banalização e a espetacularização da arte, também pautadas por Moraes, vêm de longa data e lembremos: grandes museus lucram com réplicas em chaveiros e camisetas, Tarsila do Amaral virou copo de requeijão no Brasil na 'longínqua' década de 1990 e CDs de compositores clássicos foram e são devidamente editados e oferecidos como brindes em revistas de celebridades. Até aqui nada de novo, mas a reiteração é sempre necessária para não nos iludirmos em tempos de aparente autonomia social.

Ignacio Ramonet, conhecido por sua consagrada trajetória no jornal francês $L e$ Monde Diplomatique e atuação como idealizador do Fórum Social Mundial, desenvolve um tom coloquial e mais envolvente no capítulo "Meios de comunicação: um poder a serviço de interesse privados?", e situa, neste momento, os meios de comunicação como verdadeiros entraves ao sistema democrático, "cada vez menos fiáveis e menos úteis à cidadania" (RAMONET, p. 53). Para ele, a mídia não exerce quarto poder justamente porque não admite qualquer tipo de contrapoder. Não se pode criticar ou questionar os meios de comunicação sob pena de ser tachado de antidemocrático, censurador, 
haja vista a propostas de regulação da mídia no Brasil, tão necessárias para garantir acesso e pluralidade nos sistemas midiáticos, mas que são propositalmente atacadas pela grande mídia. Moraes, inclusive, toca no aspecto da comunicação como direito humano no primeiro capítulo. Fica evidente a liberdade de empresa e não imprensa, declarada pelos autores.

Os sistemas midiáticos tradicionais enfrentam uma crise de credibilidade e, incrivelmente, rentabilidade. A afirmação vai de encontro ao colocado inicialmente por Moraes, mas trata-se de uma avaliação isolada do mercado de informação não considerando o setor de entretenimento e as "parcerias" econômicas de diferentes naturezas. Ramonet insinua que o jornalismo stricto sensu não dá lucro. Assertiva que mereceria ser problematizada.

A questão da perda de credibilidade fica mais clara. Os hábitos de leitura mudaram, o leitor não estabelece mais identidade com o veículo de comunicação, que é cada vez mais vulnerável em sua posição editorial, e na popular "dança conforme a música", não consegue fidelizar o receptor. No Brasil, isso é ainda mais pulsante do que nos exemplos franceses do autor. Estamos rodeados de veículos comprometidos economicamente, mas que pregam imparcialidade e agem de forma desonesta com o leitor. A perda de credibilidade também é atribuída à aceleração da informação, à exigência do imediatismo, que transforma o jornalista em "imedialistas". "O que fazemos é cavalgar sobre a atualidade sem a possibilidade de domesticá-la, de ter mestria nessa realidade" (RAMONET, p. 57). A ânsia da informação reduz até processos básicos do jornalismo como a pesquisa, a apuração, homogeneizando a produção e o discurso.

O alento que ele vê, e nós também, é que os cidadãos têm mais possibilidades de perceber a dissimulação e negar as falcatruas. Há atualmente nas redes o cidadão informante, produtor e consumidor de informação, mas isso não significa, em nenhuma hipótese, o fim do jornalismo. O jornalista, fazemos coro a Ramonet, deve não apenas divulgar a informação, mas apurar a veracidade, trabalhar o conteúdo, oferecer pluralidade de versões e qualidade de informação.

O espanhol Pascual Serrano diretor de redação do portal Rebelión segue na mesma toada e faz uma discussão mais densa no capítulo "Democracia e liberdade de imprensa", ressaltando a questão da fragilidade democrática dos meios de comunicação. Destaca a liberdade de imprensa/empresa como "direto do empresariado de operar num determinado setor" (SERRAno, p. 72). Na esteira de Ramonet, Serrano reitera o desvirtuamento do papel de quarto poder da imprensa, sua total negação do contrapoder e a vinculação econômica que sobrepõe, inclusive, o poder político. Seria um capítulo complementar, não fosse o esforço de Serrano em explicar as diferença entre liberdade de imprensa $\mathrm{e}$ 
expressão, a total independência uma da outra na contemporaneidade. Imprensa é empresa e expressão é participação democrática.

Ele também avalia com propriedade a posição dos sistemas midiáticos que, metaforicamente, diagnosticamos como esquizofrênica: reivindicam o direito à censura quando escolhem o que pode ser divulgado e como deve ser feito, não admitem qualquer tipo de intervencionismo do governo ou da sociedade em suas práticas e críticas, mas exigem recursos financeiros públicos quando enfrentam dificuldades econômicas.

2. “(...) o monopólio da informação que os meios de comunicação dominantes exerceram em nossas sociedades vai chegando ao fim" (RAMONET, p. 87).

Ramonet retorna na segunda parte do livro, com o tema "A explosão do jornalismo na era digital", extraído de uma conferência realizada pela Universidade de Havana, em Cuba. Um capítulo diferenciado, que traz respostas a perguntas de participantes, mas reitera muitas das ideias já expostas pelo autor na primeira parte. Como a questão do vínculo explícito com poder econômico e político, que ele rubrica como "crise habitual do jornalismo" (RAMONET, p. 86). Mas a esperança está hoje nos "meios polvos" que, diferentes dos "meios sol" (a centralizadora grande mídia), permitem a cada cidadão produzir, emitir e receber mensagens. Com isso, o autor vislumbra que o monopólio midiático vai se esgotando, em especial, os jornais com linha editorial diluída.

Um ponto autêntico dessa parte é a discussão sobre a precarização da profissão jornalista em tempos de flexibilidade e virtualização do real. Ramonet vê agora, e não sem razão, os escravos da rede - profissionais que sob as ordens da mídia convencional, devem trabalhar em tempo real, na ânsia do imediatismo, exercendo diferentes funções e degradando a profissão. Ele lembra, no entanto, que "as gerações dos últimos quinze ou vinte anos têm a melhor formação da história do jornalismo" (p. 90), mas acrescentamos que talvez sejam as piores condições de trabalho. É com muita facilidade que Ramonet transita entre diferentes temas e consegue traçar um panorama do jornalismo na era digital, destacando seus pontos fortes e fracos. Ele propõe a criação de um quinto poder pela própria sociedade, que seja capaz de vigiar o quarto poder e ressignificar a opinião pública.

Dênis de Moraes também apresenta outra perspectiva no quinto capítulo, evidenciando propostas mais participativas, que subvertem a lógica da mídia tradicional e renovam a produção e circulação de conteúdos. Em "Agências alternativas em rede e democratização da informação na América Latina", ele faz uma síntese das práticas de comunicação alternativa na América Latina, descrevendo, primeiramente, o empenho na 
defesa da democracia, desde a década de 1940, com rádios livres, parcerias com ONGs e associações sindicais e religiosas, até chegar ao jornalismo em rede e à comunicação pioneira dos zapatistas em tempos mais atuais. As TICs (Tecnologias da Informação e Comunicação) são colocadas como centrais, ferramentas determinantes para estabelecer formas de comunicação orientadas para a emancipação cidadã e política. No Brasil, ele cita as conhecidas Brasil de Fato, Agência de Informação Frei Tito para América Latina, Pulsar Brasil, Carta Maior e Ópera Mundo, que atuam com comunicação contra-hegemônica e exercem o contrapoder à mídia convencional. Mas deixa de fora importantes iniciativas alternativas como a Agência Pública, o Centro de Mídia Independente e Viomundo, que remodelaram, inclusive, o modelo de negócios do jornalismo, ao buscar financiamento público e coletivo para a produção jornalística independente. Moraes faz um alerta importante ao comentar os principais obstáculos das mídias alternativas. Ademais das dificuldades financeiras, o gargalo está na obediência a um agendamento midiático estabelecido pela mídia convencional, e na urgência da renovação de formatos e linguagens para se afastar, em definitivo, do padrão midiático atual.

No último capítulo, "Outro jornalismo possível na internet", Pascual Serrano também se dedica a mostrar alternativas à mídia hegemônica, por meio, entre outros, do seu próprio portal Rebelión. Ele insiste nas crises do jornalismo: de mediação, de credibilidade, de objetividade, de autoridade, de informação e de distribuição, mas acena para uma nova forma de produzir, acessar, consumir e distribuir notícia. Os portais alternativos ganham espaço e devem, na visão do autor, "desbancar o modelo dominante" e não meramente ficarem na marginalidade, chancelados como minoritários (SERRANo, p. 115).

De maneira mais propositiva, ele orienta que para pensar uma mídia digital legítima é preciso resolver questões técnicas, definir os destinatários, discutir constantemente as políticas editoriais e se abrir para a pluralidade e para a divulgação de fatos fora do próprio âmbito de interesse ideológico, e apostar na colaboração: palavra de ordem da web 2.0. Serrano contesta os meios panfletários e prega uma prática jornalística isenta um projeto de comunicação e não de ativismo social. Mas aqui há algo de contraditório no pensamento do autor, pois ele mesmo defende o envolvimento com os debates de rua, uma imprensa de opinião com posição definida e chega a afirmar que "espancar teclados" pode ser irrelevante se não houver ação organizativa. Portanto, isenção não deve ser a palavra de ordem, mas sim comprometimento, com as causas sociais e com a qualidade do jornalismo.

Em suma, o livro dos três intensos autores pode até não trazer fatos novos, mas nos avisa que, na atual conjuntura, não há como ficar inerte. Pensar a comunicação exige uma tomada de posição imediata. Exige o contrapoder já proclamado desde o título. 